\title{
ANALISIS PENGARUH PELATIHAN DAN PROMOSI TERHADAP PRESTASI KERJA PADA DINAS PERTANIAN DAN PETERNAKAN KABUPATEN PINRANG
}

\author{
Sitti Mujahida Baharuddin ${ }^{1}$, Warka Syachbrani ${ }^{2}$ \\ Dosen Prodi Manajemen, Sekolah Tinggi Ilmu Ekonomi Amkop Makassar \\ Email:mujahida-41@yahoo.com¹, warka.syachbrani@unm.ac.id ${ }^{2}$
}

(Diterima: 17 September 2019; direvisi:25 September 2019; dipublikasikan:Oktober 2019)

(C2019 -Bongaya Journal for Research inManagement STIEM Bongaya. Ini adalah artikel dengan akses terbuka dibawah licenci CC BY-NC-4.0 (https://creativecommons.org/licenses/by-nc/4.0/).

\begin{abstract}
This study aims to analyze and describe the effect of training and promotion on work performance. This research is an explanatory research. In this study, the population is all of the Employees of the Agriculture and Animal Husbandry Office of Pinrang Regency, amounting to 57 people. The results showed that training had a positive and significant effect on work performance and positive and significant promotions on employee performance. Work performance has a positive and significant effect on training and promotion.
\end{abstract}

Keywords: Training; Promotion; Work performance

\begin{abstract}
Abstrak:Penelitian ini bertujuan untuk menganalisis dan mendeskripsikan pengaruh pelatihan dan promosi terhadap prestasi kerja. Penelitian ini merupakan explanatory research, Dalam penelitian ini populasinya adalah seluruh Pegawai Kantor Dinas Pertanian dan Peternakan Kabupaten Pinrang yang berjumlah 57 orang. Hasil penelitian menunjukkan bahwa pelatihan berpengaruh positif dan signifikan terhadap prestasi kerja dan promosi positif dan signifikan terhadap prestasi kerja pegawai. Prestasi kerja berpengaruh positif dan signifikan terhadap pelatihan dan promosi.
\end{abstract}

Kata kunci: Pelatihan; Promosi;Prestasi kerja

\section{PENDAHULUAN}

Pencapaian prestasi kerja pegawai sering menjadi masalah pada hampir setiap organisasi. Bagi organisasi, prestasi kerja pegawai menjadi syarat penting bagi tercapainya tujuan organisasi secara efektif dan efisien. Gibson, et.,al., (2009:75) mendefinisikan prestasi kerja sebagai hasil kerja pegawai yang diperoleh dari gabungan perilaku pegawai dan organisasi/organisasi. Prestasi kerja pegawai adalah tujuan setiap organisasi. Dengan memiliki pegawai yang berprestasi maka hal tersebut akan mampu mendorong kinerja organisasi secara keseluruhan, sebab pegawai yang berprestasi memiliki ciri sebagai orang yang haus dengan pencapaian-pencapaian terbaik. Sekumpulan individu-individu yang berhasil mencapai apa yang diinginkannya, maka akan terakumulasi menjadi sekelompok individu di dalam organisasi yang menjadi ujung tombak organisasi dalam rangka mencapai kinerja yang optimal.

Pegawai baru bisa memiliki prestasi kerja yang baik apabila didukung oleh faktor yang mempengaruhinya. Banyak hasil penelitian mengungkapkan bahwa faktor yang mempengaruhi prestasi kerja adalah Pelatihan (Ratnasari, 2013; Warnanti, 2014 ); Promosi dan Mutasi (Judas; 2013)

Globalisasi pada saat ini mendorong organisasi agar responsif dalam meningkatkan keterampilan dan kualitas sumber daya manusia yang dimiliki agar bisa bersaing dengan organisasi sejenis. Kemampuan sumber daya manusia dalam menjalankan tugas-tugas organisasi harus diperhatikan, salah satunya dengan cara meningkatkan kemampuan sumber 
daya manusia dalam menjalankan tugas-tugas organisasi melalui pelatihan atau training. Melalui pelatihan dan pengembangan diharapkan dapat menambah pengetahuan dan keterampilan sumber daya manusia dalam menjalankan tugas yang dibebankan organisasi (Handoko, 2001:104).

Selain pelatihan, promosi juga merupakan faktor yang ikut berpengaruh terhadap prestasi kerja. Oleh karena dengan adanya kesempatan promosi yang diberikan oleh pihak organisasi kepada pihak pegawai dengan demikian akan tercipta suatu keinginan dari pegawai untuk memotivasi dirinya sendiri. Kemungkinan promosi yang lebih besar dapat dilihat bukan saja pada peningkatan penghasilan akan tetapi sebagai penghargaan atas kemampuan yang semakin meningkat sehingga kepadanya dapat diberikan wewenang dan tanggung jawab yang lebih besar dan lebih luas, yang pada gilirannya dapat meningkatkan motivasi kerja pegawai yang sekaligus menambah kepuasan batin.

Permasalahan yang muncul terkait dengan sistem promosi jabatan saat ini adalah terletak pada proses evaluasi untuk mempromosikan seseorang, dimana karyawan dipromosikan ke jabatan yang lebih tinggi dengan hanya melihat dari satu kriteria penilaian, yang pada kenyataannya karyawan tersebut belum tentu unggul pada beberapa kriteria lainnya (Siagian, 2014:170). Penelitian Fanada (2012) mengatakan bahwa, dalam promosi jabatan, pimpinan cenderung melakukan penilaian bukan berdasarkan prestasi kerja tetapi lebih pada faktor kedekatan (persaudaraan) dan juga faktor suka tidak suka. Setiawan dan Sariyathi (2013), yang melakukan penelitian pada industri pariwisata di Bali, mengatakan jika sistem promosi yang diterapkan tidak mencerminkan rasa keadilan bagi karyawan tentu akan berimplikasi pada menurunnya kepuasan kerja karyawan dalam bekerja serta pada akhirnya menurunkan kinerja mereka.

\section{TINJAUAN PUSTAKA}

\section{Manajemen Sumber Daya Manusia}

Manajemen sumber daya manusia mengembangkandan mencapai sasaran-sasaran organisasi, adalah tugas manajemen sumber daya manusia untuk mengelola unsur secara baik agar diperoleh tenaga kerja yang puas akan pekerjaannya.

Manajemen sumber daya manusia adalah suatu bidang manajemen yang khususmempelajari hubungan dan peranan manusia dalam organisasi perusahaan. Unsur manajemen sumber daya manusia adalah manusia yang merupakan tenaga kerja pada perusahaan. Dengan demikian, fokus yang dipelajari manajemen sumber daya manusia ini hanyalah masalah yang berhubungan dengan tenaga kerja manusia saja.

Menurut Soeprihanto (2007:3) dalam bukunya manajemen personalia mendefinisikansebagai berikut : "Manajemen sumber daya manusia adalah seni dan ilmu perencanaan,pengorganisasian, pengarahan, dan pengawasan terhadap pelaksanaan fungsi pengadaan atau penarikan, pengembangan, pemberian kompensasi, pengintegerasian, dan pemeliharaan tenaga kerja dengan maksud membantu kearah tercapainya tujuan organisasi, perusahaan, individu, diri para pekerja dan masyarakat".

\section{Pelatihan}

\section{a. Pengertian Pelatihan}

Pelatihan merupakan kegiatan yang lebih banyak ditujukan pada pengembangan pegawai baik dalam bidang kecakapan, pengetahuan, ketrampilan, keahlian, sikap dan tingkah laku pegawai serta lebih kepada sifat praktis. Efisiensi suatu perusahaan sangat tergantung pada tingkat kualitas sumber daya manusia yang dimiliki oleh perusahaan. Menyadari peran penting sumber daya manusia yang berkualitas maka salah satu cara yang dilakukan pemerintah untuk meningkatkan kualitas para karyawannya adalah melalui kegiatan pelatihan kerja. Swasto (2011:65) mengungkapkan bahwa pelatihan berkaitan dengan ketrampilan (skill) dan diutamakan untuk keperluan masa sekarang. Handoko (2001:104) mengemukakan pendapatnya mengenai pelatihan, yaitu sebagai berikut : "Latihan (training) dimaksudkan untuk memperbaiki penguasaan berbagai ketrampilan dan teknik pelaksanaan kerja tertentu, terinci dan rutin. Latihan menyiapkan para karyawan untuk melakukan pekerjaan-pekerjaan sekarang. Di lain pihak, bila manajemen ingin menyiapkan para karyawan untuk memegang tanggung jawab pekerjaan di waktu yang akan datang dan kegiatan ini disebut dengan pengembangan sumber daya manusia". Oleh sebab itu pelatihan kerja hendaknya 


\section{3 | Bongaya Journal for Research in Management Vol.2 No. 2 Oktober 2019}

dilaksanakan secara bertahap mengingat perkembangan lingkungan organisasi berlangsung dengan cepat dan mempengaruhi kehidupan organisasi dalam perusahaan.

Pelatihan menurut Dessler (2007:216) adalah proses mengajarkan karyawan baru atau yang ada sekarang, ketrampilan dasar yang mereka butuhkan untuk menjalankan kebutuhan mereka. Sedangkan menurut Mathis (2009:302), pelatihan adalah suatu proses dimana orang-orang mencapai kemampuan tertentu untuk membantu mencapai tujuan organisasi. Jadi, proses pelatihan memiliki keterikatan dengan berbagai tujuan organisasi.

Pengertian pelatihan itu sendiri menurut Nitisemito (2002:26), adalah sebagai berikut: "Pelatihan adalah suatu kegiatan dari perusahaan yang dimaksud untuk memperbaiki dan mengembangkan sikap, tingkah laku, keterampilan dan pengetahuan dari para karyawan sesuai dengan keinginan dari perusahaan yang bersangkutan".

Menurut Tanjung (2005:143), mengemukakan bahwa : "Pelatihan merupakan salah satu usaha untuk mengembangkan sumber daya manusia, terutama dalam hal pengetahuan (knowledge), kemampuan (ability), keahlian (skill) dan sikap (attitude)".

\section{b. Sasaran Pelatihan}

Menurut Nitisemito (2002:28) bahwa dalam program pelatihan terdapat beberapa sasaran yang hendak dicapai antara lain:

1) Pekerjaan yang dibebankan diharapkan dapat lebih cepat terselesaikan dan hasilnya dapat lebih baik.

2) Penggunaan peralatan mesin perusahaan diharapkan dapat bertahan lebih lama.

3) Angka kecelakaan kerja pada karyawan diharapkan dapat menurun.

4) Tanggungjawab karyawan diharapkan lebih besar.

5) Biaya produksi perusahaan diharapkan lebih rendah.

6) Kelangsungan hidup perusahaan lebih terjamin.

\section{c. Tujuan Pelatihan}

1) Meningkatkan produktivitas kerja.

2) Meningkatkan kualitas.

3) Memperbaiki iklim organisasi.

4) Membantu perusahaan dalam menentukan tenaga kerja di masa yang akan datang.

5) Pertumbuhan pribadi.

\section{Promosi}

a. Pengertian

Pengertian Promosi Jabatan yaitu Sehubungan dengan prinsip yang dimiliki perusahaan pada umumnya yaitu going concern dan profit motif maka unsur produktifitas kerja yang harus dapat dicapai oleh setiap individu yang ada didalam perusahaan adalah produktifitas yang maksimal. Hal ini memberikan pengertian bahwa manajemen harus selalu mampu mendorong para karyawannya untuk bekerja dengan baik dan lebih baik dari sebelumnya, serta memberikan kepastian kepada mereka promosi jabatan yang lebih tinggi bagi yang mampu memberikan kontribusi prestasi lebih bagi perusahaan. Promosi jabatan disini akan berarti perluasan dari tugas, wewenang dan tanggung jawab yang bersangkutan sebelumnya, sekaligus peningkatan kesejahteraan bagi yang menerimanya. Promosi mempunyai nilai sendiri karena merupakan bukti pengukuhan terhadap prestasinya sehingga dengan promosi jabatan bagi pegawai yang mempunyai prestasi yang tinggi, akan dapat ditingkatkan jabatannya sesuai dengan kemampuannya.

Menurut Nitisemito

"Promosi adalah proses pemindahan karyawan dari satu jabatan ke jabatan lain yang lebih tinggi yang selalu diikuti oleh tugas, tanggung jawab dan wewenang yang lebih tinggi pula dari jabatan yang diduduki sebelumnya."

Nasution (2000:140) mendefinisikan bahwa promosi adalah proses bergerak maju dan meningkat dalam suatu jabatan yang didudukinya. Menurut Siagian (2014: 169) promosi adalah perpindahan pegawai dari satu pekerjaan ke pekerjaan lain yang tanggung jawabnya lebih besar, tingkatan hirarki jabatannya lebih tinggi dan penghasilannya pun lebih besar pula.

Promosi jabatan merupakan perkembangan yang positif dari seorang pekerja atau pegawai karena tugasnya dinilai baik oleh pejabat yang berwenang. Oleh karena itu, pemberian tanggung jawab dan kewenangan yang lebih tinggi patut diberikan kepada mereka yang berprestasi. Fathoni (2006:112) Promosi jabatan adalah peningktan dari seorang tenaga kerja atau pegawai pada suatu bidang tugas yang lebih baik, dibanding dengan sebelumnya dari sisi tanggung jawab yang lebih besar, prestasi, fasilitas, status yang lebih tinggi, tuntutan 
Sitti Mujahida Baharuddin, Warka Syachbrani,Analisis Pengaruh Pelatihan dan Promosi Terhadap Prestasi Kerja Pada Dinas Pertanian Dan Peternakan Kabupaten Pinrang | 34

kecakapan yang lebih tinggi, dan adanya penambahan upah atau gaji serta tunjangan lain.

Menurut Manullang (2008:153) bahwa promosi berarti kenaikan jabatan, yakni menerima kekuasaan dan tanggung jawab lebih besar dari kekuasaan dan tanggung jawab sebelumnya dalam struktur organisasi sesuatu badan usaha.

Hasibuan (2011:108) Promosi adalah perpindahan yang memperbesar wewenang dan tanggung jawab karyawan ke jabatan yang lebih tinggi di dalam organisasi kewajiban, hak, status dan penghasilannya semakin besar.

\section{b. Faktor-faktor yang Mempengaruhi Promosi Jabatan \\ Untuk mencapai tujuan promosi, maka hendaknya promosi jabatan dilakukan berdasarkan azas-azas promosi jabatan sebagaimana Hasibuan (2011 : 108-109) mengemukakan bahwa :}

1) Kepercayaan Promosi hendaknya berazaskan pada kepercayaan atau keyakinan mengenai kejujuran, kemampuan dan kecakapan karyawan yang bersangkutan dalam melaksanakan tugas-tugasnya dengan baik pada jabatan tersebut.

2) Keadilan Promosi. Promosi hendaknya berazaskan kepada keadilan, mengenai penilaian kejujuran, kemampuan dan kecakapan terhadap semua karyawan. Penilaian harus jujur dan objektif jangan pilih kasih,tanpa melihat suku, golongan dan keturunannya.

3) Formasi Promosi harus berazaskan kepada promosi yang ada, karena promosi karyawan hanya mungkin dilakukan jika ada formasi jabatan yang lowong, supaya ada uraian pekerjaan yang akan dilaksanakan karyawan tersebut.

Untuk melaksanakan promosi jabatan perusahaan harus menetapkan syarat-syaratnya terlebih dahulu yang dapat menjamin bahwa karyawan yang akan dipromosikan akan mempunyai kemampuan untuk menjabat jabatan yang lebih tinggi, seperti yang dikemukakan oleh Alex S. Nitisemito (2002 : 112-113) pada umumnya yaitu :

1) Pengalaman Dengan pengalaman yang lebih banyak diharapkan kemampuan yang lebih tinggi, ide yang lebih banyak dan sebagainya.
2) Tingkat pendidikan Bahwa dengan pendidikan yang lebih tinggi dapat diharapkan pemikiran yang yang lebih baik.

3) Loyalitas. Dengan loyalitas yang tinggi dapat diharapkan antara lain tanggung jawab yang lebih besar.

4) Kejujuran Masalah kejujuran merupakan syarat yang penting, misalnya kasir pada umumnya syarat kejujuran merupakan syarat umum yang harus diperhatikan. 5) Tanggung jawab Kadang-kadang seringkali suatu perusahaan diperlukan suatu tanggung jawab yang cukup besar, sehingga masalah tanggung jawab merupakan syarat utama untuk promosi.

6) Kepandaian bergaul. Untuk Kepandaian bergaul Untuk promosi jabatan tertentu mungkin diperlukan kepandaian bergaul, sehingga persyaratan kemampuan bergaul dengan orang lain perlu dibutuhkan untuk promosi jabatan tersebut, misalnya jabatan untuk salesman penetapan syarat tersebut adalah sangat penting.

7) Prestasi kerja. Pada umumnya setiap perusahaan selalu mencantumkan syarat-syarat untuk berprestasi kerjanya dan ini dapat dilihat dari catatan-catatan prestasi yang telah dikerjakan.

8) Inisiatif dan kreatif Syarat tingkat inisiatif dan kreatif merupakan syarat yang harus diperhatikan. Hal ini disebabkan karena untuk jabatan tersebut sangat diperlukan inisiatif dan kreatif, meskipun demikian tidak setiap perusahaan menentukan hal itu sebagai syaratnya.

\section{c. Manfaat Promosi}

Jabatan Setiap perusahaan mempunyai manfaat yang berbeda-beda dalam mempromosikan para karyawan ke jenjang yang lebih tinggi, namun disesuaikan dengan kebutuhan perusahaan tersebut. Menurut Henry Simamora (Simamora, 2004:587) manfaat dari promosi adalah sebagai berikut:

1) Promosi memungkinkan perusahaan untuk mendayagunakan keahlian dan kemampuan karyawan setinggi mungkin.

2) Promosi seringkali diberikan karyawan yang berkinerja sangat baik. Karyawan yang dihargai promosi akan termotivasi untuk memberikan kinerja yang lebih tinggi lagi jika mereka merasa bahwa 
kinerja yang efektif menyebabkan promosi.

3) Riset memperlihatkan bahwa kesempatan untuk promosi dan tingkat kepuasan kerja yang sangat tinggi berkorelasi secara signifikan. Sistem promosi karyawan yang efektif dapat menyebabkan efisiensi organisasional yang lebih besar dan tingkat moral kerja karyawan yang tinggi.

Jadi promosi bermanfaat bagi perusahaan dan karyawan. Bagi perusahaan promosi bermanfaat untuk mendayagunakan kemampuan karyawan setinggi mungkin. Sedangkan, bagi karyawan memberikan motivasi untuk bekerja lebih serius lagi.

\section{d. Tujuan Promosi}

Menurut Manullang (2008:109), perusahaan perlu melakukan promosi untuk mempertinggi semangat kerja karyawan, kemudian dapat menjamin stabilitas kekaryawanan. Jabatan Pada dasarnya promosi pegawai diarahkan kepada peningkatan dari ketetapan perusahaan dalam mencapai sasaran melalui pelaksanaan promosi jabatan dimana peran pegawai tersebut memperoleh kepuasan kerja sehingga memungkinkan seorang pegawai untuk memberikan hasil kerja yang terbaik kepada perusahaan sehingga dapat ditetapkan tujuan promosi sebagaimana yang dikemukakan Hasibuan (2011 : 113), yaitu :

1) Untuk memberikan pengakuan, jabatan, dan imbalan jasa yang semakin besar kepada karyawan yang berprestasi kerja lebih tinggi.

2) Dapat menimbulkan kepuasan dan kebanggan pribadi, status sosial yang semakin tinggi, dan penghasilan yang semakin besar.

3) Untuk merangsang agar karyawan lebih bergairah bekerja, berdisiplin tinggi, dan memperbesar produktivitas kerja.

4) Untuk menjamin stabilitas kepegawaian dengan direalisasikan promosi kepada karyawan dengan dasar dan pada waktu yang tepat serta penilaian yang jujur.

5) Kesempatan promosi dapat menimbulkan keuntungan berantai (multiplier effect) dalam perusahaan karena timbul lowongan berantai.

6) Memberikan kesempatan kepada karyawan untuk mengembangkan kreativitas dan inovasinya yang lebih baik demi keuntungan optimal perusahaan.

7) Untuk menambah/memperluas pengetahuan serta pengalaman kerja para karyawan dan ini merupakan daya dorong bagi karyawan lainnya.

8) Untuk mengisi kekosongan jabatan karena pejabatnya berhenti. Agar jabatan itu tidak lowong maka dipromosikan karyawan lainnya.

9) Karyawan yang dipromosikan kepada jabatan yang tepat, semangat kesenangan, dan ketenangannya dalam bekerja semakin meningkat sehingga kinerjanya semakin meningkat.

10) Untuk mempermudah penarikan pelamar, sebab dengan adanya kesempatan promosi merupakan daya pendorong serta perangsang bagi pelamar untuk memasukan lamarannya.

11) Promosi akan memperbaiki status karyawan dari karyawan sementara menjadi karyawan tetap setelah lulus dari masa percobaannya. Maka dapat disimpulkan bahwa promosi jabatan bertujuan untuk menunjang kegiatan perusahaan atau pelaksanaan fungsi-fungsi manajemen sumber daya manusia secara keseluruhan

\section{Prestasi Kerja}

\section{a. Pengertian Prestasi Kerja}

Setiap perusahaan pada dasarnya menginginkan dan menuntut agar seluruh karyawan selalu menyelesaikan pekerjaannya dengan sebaik mungkin. Namun karyawan tidak dapat diperlakukan seenaknya seperti menggunakan faktor-faktor produksi lainnya (mesin, modal dan bahan baku). Karyawan juga harus selalu diikutsertakan dalam setiap kegiatan serta meberikan peran aktif untuk menggunkan alatalat yang ada. Karena tanpa peran aktif karyawan, alat-alat canggih yang dimiliki tidak ada artinya bagi perusahaan untuk mencapai tujuan.

Suatu instansi atau perusahaan tentunya memiliki tujuan, tujuan inilah yang membuat instansi atau perusahaan tersebut ada namun terkadang muncul kendala yang membuat tujuan tersebut tidak tercapai. Untuk mencegahnya maka perusahaan harus mendorong karyawan untuk mencapai kinerja dan prestasi yang lebih baik dari waktu ke waktu. Hasibuan (2011:87) Prestasi kerja adalah suatu hasil kerja yang dicapai seseorang 
Sitti Mujahida Baharuddin, Warka Syachbrani,Analisis Pengaruh Pelatihan dan Promosi Terhadap Prestasi Kerja Pada Dinas Pertanian Dan Peternakan Kabupaten Pinrang 36

dalam melakukan tugas- tugas yang dibebankan kepadanya yang didasarkan pada kecakapan, pengalaman, dan kesungguhan serta ketepatan waktu.

Prestasi kerja merupakan hasil kerja yang dicapai seseorang. Menurut Mangkunegara (2009:67), istilah prestasi kerja atau kinerja berasal dari kata Job Performance yaitu prestasi kerja atau Actual Performance yaitu prestasi sesungguhnya yang dicapai oleh seseorang. Ukuran terakhir keberhasilan departemen personalia adalah prestasi atau pelaksanaan kerja karyawan, baik departemen personalia maupun

para karyawan memerlukan umpan balik upayaupaya mereka (Handoko, 2008:135).

Prestasi kerja/penilaian kinerja adalah hasil kinerja secara kualitas atau kuantitas yang dicapai oleh seorang karyawan dalam melaksanakan tugasnya sesuai dengan tanggung jawab yang diberikan kepadanya. Menurut Suprianto (2002:7) prestasi kerja adalah hasil kerja seseorang karyawan selama periode tertentu dibandingkan dengan berbagai kemungkinan, misalnya standar, target/sasaran atau kriteria yang telah ditentukan terlebih dahulu dan disepakati bersama.

\section{b. Faktor-Faktor yang Mempengaruhi Prestasi Kerja}

Suprianto (2002:25) memperinci faktorfaktor yang mempengaruhi prestasi kerja menjadi kualitas pekerjaan, kuantitas pekerjaan, kemampuan bekerja sendiri, pemahaman dan pengenalan pekerjaan dan kemampuan memecahkan persoalan yang dicapai oleh seorang karyawan. Mangkunegara (2009:16) menyimpulkan bahwa faktor-faktor penentu prestasi kerja dalam perusahaan adalah sebagai berikut :

1) Faktor Individu Secara psikologis, individu normal adalah individu yang memiliki integritas yang tinggi antara fungsi psikis (rohani) dan fisiknya (jasmani). Dengan adanya integritas yang tinggi antara fungsi psikis dan fisik, maka individu tersebut memiliki konsentrasi diri yang baik. Konsentrasi ini sangat dipengaruhi oleh kemampuan potensi yaitu kecerdasan pikiran / IQ dan kecerdasan emosi / EQ. Pada umumnya individu mampu bekerja dengan penuh konsentrasi apabila memiliki tingkat intelegensi minimal normal dengan tingkat kecerdasan emosi baik, tidak mudah marah, tidak benci, tidak iri hati, tidak sombong, tidak minder, tidak cemas, tidak dendam, memiliki pandangan dan pedoman hidup yang jelas.

2) Faktor Lingkungan Kerja Organisasi. Faktor lingkungan kerja organisasi yang dimaksud antara lain uraian jabatan yang jelas, autoritas memadai, target kerja menantang, pola komunikasi kerja efektif, hubungan kerja harmonis, iklim kerja respek dan dinamis, peluang berkarier dan fasilitas kerja yang relatif memadai. Bagi individu, lingkungan kerja organisasi

dapat diciptakan bahkan diubah sekaligus merupakan pemicu (pemotivasi), tantangan bagi dirinya dalam berprestasi di organisasinya.

\section{A. Kerangka Pikir}

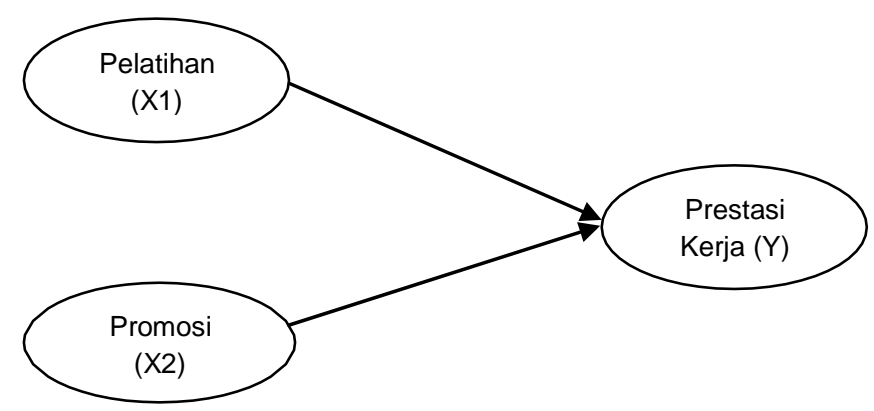

\section{B. Hipotesis}

1. Pelatihan berpengaruh signifikan terhadap Prestasi Kerja Pegawai pada Dinas Pertanian dan Peternakan Kabupaten Pinrang

2. Promosi berpengaruh signifikan terhadap Prestasi Kerja Pegawai pada Dinas Pertanian dan Peternakan Kabupaten Pinrang

3. Pelatihan berpengaruh dominan terhadap Prestasi Kerja Pegawai pada Dinas Pertanian dan Peternakan Kabupaten Pinrang.

\section{PEMBAHASAN}

A. Hasil Penelitian

\section{Pengujian Keabsahan Data}

Dalam suatu penelitian kesahihan (validitas) dan kehandalan (reliabilitas) suatu hasil penelitian tergantung pada alat pengukur (instrumen) yang digunakan dan data yang 
diperoleh. Untuk itu perlu dilakukan pengujian yaitu tes kesahihan (test of valitity) dan tes kehandalan (test of realibility).

\section{a. Hasil Uji Validitas}

Daftar pertanyaan atau kuesioner merupakan data primer yang sangat menunjang dalam pelaksanaan penelitian. Oleh karena itu perlu dilakukan uji validitas untuk mengetahui apakah daftar pertanyaan yang telah disiapkan dapat mengukur variabel yang akan diukur. Uji validitas dilakukan dengan cara menghitung korelasi antara masing-masing daftar pertanyaan dengan skor totalnya. Hasil pengujian validitas yang dilakukan dapat dilihat pada tabel 4.1.

Tabel 4.1

Hasil Uji Validitas

\begin{tabular}{|c|c|c|c|}
\hline Korelasi antara & $\begin{array}{l}\text { Nilai kocelasi } \\
\text { (Pearson } \\
\text { Correlation) }\end{array}$ & $\begin{array}{l}\text { Rrobabilitas } \\
\text { Korelasi [Isig } \\
\text { [2-tailed] }\end{array}$ & Keterangan \\
\hline X1.1 dengan Total & 0,929 & 0,000 & valid \\
\hline X1.2 dengan Total & 0,935 & 0,000 & Valid \\
\hline X1.3 dengan Total & 0,871 & 0,000 & Valid \\
\hline X1.4 dengan Total & 0,923 & 0,000 & valid \\
\hline X1.5 dengan Total & 0,899 & 0,000 & valid \\
\hline X1.6 dengan Total & 0,834 & 0,000 & Valid \\
\hline x1.7 dengan Total & 0,853 & 0,000 & valid \\
\hline X1.8 dengan Total & 0,868 & 0,000 & valid \\
\hline X1.9 dengan Total & 0,874 & 0,000 & valid \\
\hline x1.10 dengan Total & 0,769 & 0,000 & Valid \\
\hline X1.11 dengan Total & 0,796 & 0,000 & valid \\
\hline X1.12 dengan Total & 0,577 & 0,000 & valid \\
\hline X2.1 dengan Total & 0,584 & 0,000 & Valid \\
\hline X2.2 dengan Total & 0,856 & 0,000 & Valid \\
\hline X2.3 dengan Total & 0,525 & 0,000 & valid \\
\hline X2.4 dengan Total & 0,888 & 0,000 & valid \\
\hline Y1.1 dengan Total & 0,855 & 0,000 & valid \\
\hline Y1.2 dengan Total & 0,758 & 0,000 & Valid \\
\hline Y1.3 dengan Total & 0,776 & 0,000 & valid \\
\hline Y1.4 dengan Total & 0,766 & 0,000 & valid \\
\hline Y1.5 dengan Total & 0,670 & 0,000 & Valid \\
\hline
\end{tabular}

Sumber data diolah 2019

Berdasarkan tabel 4.1, dapat diketahui bahwa semua butir pertanyaan yang diajukan kepada responden adalah valid, dimana mempunyai nilai korelasi yang lebih besar daripada nilai kritisnya atau bisa dilihat dari nilai koefisien korelasi dari masing-masing item memiliki nilai $>0,3$ dan nilai probabilitas korelasi [sig (2tailed $<$ dari taraf signifikansi $(\alpha)$ sebesar 0,05$]$.

\section{b. Hasil Uji Reliabilitas}

Pengujian reliabilitas dengan menggunakan teknik alpha. Suatu konstruk atau variabel dikatakan reliabel jika memberikan nila Cronbach Alpha> 0,60.Hasil pengujian reliabilitas yang dilakukan dapat dilihat pada tabel 4.2.

\section{Tabel $\quad 4.2$}

\section{Hasil Uji Reliabilitas}

\begin{tabular}{|c|c|c|c|c|}
\hline No & Variabel & $\begin{array}{c}\text { Croncbach } \\
\text { Alpha }\end{array}$ & $\begin{array}{c}\text { Hasil } \\
\text { Perhitungan }\end{array}$ & $\begin{array}{c}\text { Jumlah } \\
\text { Butir } \\
(\mathbf{N})\end{array}$ \\
\hline 1 & $\mathrm{X} 1$ & $>0,60$ & 0,964 & 12 \\
2 & $\mathrm{X} 2$ & $>0,60$ & 0,621 & 4 \\
3 & $\mathrm{Y}$ & $>0,60$ & 0,783 & 5 \\
\hline
\end{tabular}

Berdasarkan Tabel 4.2, pada pengujian reliabilitas dengan ukuran sampel sebanyak 57 responden, dapat diketahui bahwa nilai dari Croncbach Alpha untuk variabel Pelatihan (X1), variabel Promosi (X2) dan variabel Prestasi Kerja (Y) > 0,60, maka dapat disimpulkan bahwa variabel Pelatihan (X1), variabel Promosi (X2) dan variabel Prestasi Kerja (Y) bersifat Reliabel atau dapat dipercaya.

\section{Uji Asumsi Klasik}

Sebelum melakukan analisis model regresi yang akan digunakan dalam penelitian ini, terlebih dahulu dilakukan uji asumsi klasik agar hasil kesimpulan yang diperoleh tidak menimbulkan nilai yang bias. Adapun uji asumsi klasik dalam penelitian ini meliputi Uji Multikolinearitas, Uji Heteroskedastisitas, Uji Autokorelasi, dan Uji Normalitas.

\section{a. Uji Multikolinearitas}

Uji multikolinearitas bertujuan untuk menguji apakah model regresi ditemukan adanya korelasi antar variabel bebas (independent). Model regresi yang baik seharusnya tidak terjadi korelasi diantara variabel independent. Hasil uji multikolinearitas dapat dilihat pada Tabel 4.3.

Tabel 4.3

\section{Hasil Uji Multikolinearitas}

\begin{tabular}{|c|c|c|c|}
\hline Variabel & Tolerance & VIF & Keterangan \\
\hline $\begin{array}{c}\text { Pelatihan } \\
(\mathrm{X} 1)\end{array}$ & 1,000 & 1,000 & $\begin{array}{c}\text { Tidak ada } \\
\text { Multikolinearitas }\end{array}$ \\
\hline $\begin{array}{c}\text { Promosi } \\
(\mathrm{X} 2)\end{array}$ & 1,000 & 1,000 & $\begin{array}{c}\text { Tidak ada } \\
\text { Multikolinearitas }\end{array}$ \\
\hline
\end{tabular}


Sitti Mujahida Baharuddin, Warka Syachbrani,Analisis Pengaruh Pelatihandan Promosi Terhadap Prestasi Kerja Pada Dinas Pertanian Dan Peternakan Kabupaten Pinrang|38

Sumber : Hasil Olah Data, 2019

Berdasarkan Tabel 4.3, dapat diketahui bahwa semua variabel bebas mempunyai nilai Tolerance

\begin{tabular}{|c|c|}
\hline Model & Durbin-Watson \\
\hline 1 & 1,983 \\
\hline
\end{tabular}

lebih besar dari 0,1 dan nilai Variance Inflation Factor (VIF) kurang dari 10, maka dapat disimpulkan bahwa tidak terjadi masalah multikolinearitas dalam model penelitian ini.

\section{a. Uji Heteroskedastisitas}

Untuk mendeteksi ada tidaknya heteroskedastisitas dengan melihat pola titik-titik pada scatterplot regresi. Jika titik-titik menyebar dengan pola yang tidak jelas di atas dan di bawah angka 0 pada sumbuh $\mathrm{Y}$ maka tidak terjadi masalah heteroskedastisitas. Scatterplot dapat dilihat pada output regresi dan disajikan dalam bentuk Gambar 4.1.

\section{Gambar 4.1}

Hasil Uji Heteroskedastisitas

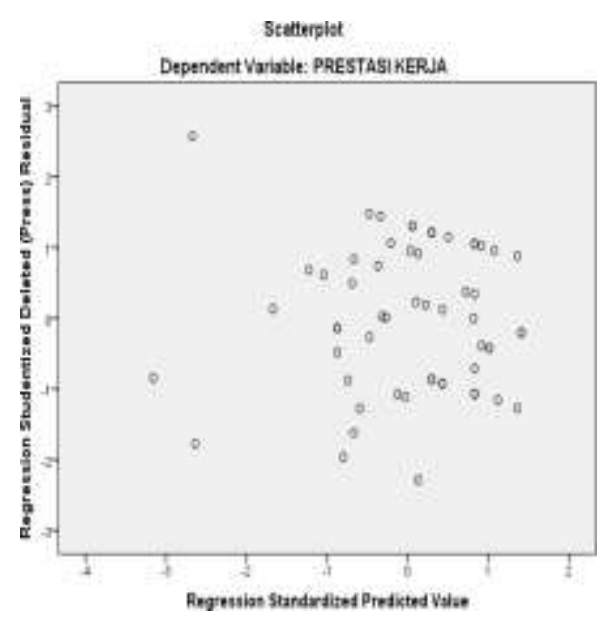

Berdasarkan Gambar Scatterplot 4.1, dapat diketahui bahwa titik-titik menyebar dengan pola yang tidak jelas di atas dan di bawah angka 0 pada sumbu Y, maka pada model regresi tidak terjadi masalah heteroskedastisitas.

a. Uji Autokorelasi

Persamaan regresi yang baik adalah yang tidak memiliki masalah autokorelasi, jika terjadi autokorelasi maka persamaan tersebut menjadi tidak baik/tidak layak dipakai prediksi. Masalah autokorelasi baru timbul jika ada korelasi secara linier antara kesalahan penggangu periode $\mathrm{t}$ (berada) dengan kesalahan pengganggu periode t-1 (sebelumnya). Untuk mendeteksi ada tidaknya autokorelasi dengan dilakukan uji Durbin-Watson. Hasil uji Durbin-Watson dapat dilihat pada output regresi dan disajikan pada Tabel 4.4

Tabel 4.4

Hasil Uji Autokorelasi Model Summary ${ }^{b}$

a. Predictors: (Constant), , Promosi (X2), Pelatihan (X1)

b. Dependent Variable: Prestasi Kerja (Y)

Sumber : Hasil Olah Data, 2019

Berdasarkan Tabel 4.4, menunjukkan nilai Durbin-Watson test $=1,983$ berada di antara -2 dan +2 , dengan demikian dari hasil pengujian ini dapat disimpulkan bahwa tidak terjadi autokorelasi pada persamaan regresi penelitian ini.

\section{b.Uji Normalitas}

Untuk menguji data berdistribusi normal atau tidak, menggunakan uji Kolmogorov Smirnov satu arah. Pengambilan kesimpulan untuk menentukan apakah suatu data mengikuti distribusi normal atau tidak adalah dengan menilai nilai signifikannya. Jika signifikan > 0,05 maka variabel berdistribusi normal dan sebaliknya jika signifikan $<0,05$ maka variabel tidak berdistribusi normal

Tabel 4.5

Hasil Uji

Normalitas

One-Sample Kolmogorov-Smirnov Test

\begin{tabular}{|c|c|c|}
\hline & & $\begin{array}{c}\text { Unstandardized } \\
\text { Predicted } \\
\text { Value }\end{array}$ \\
\hline \multicolumn{2}{|l|}{$\mathrm{N}$} & 57 \\
\hline & Mean & 16,2280702 \\
\hline \multirow[t]{2}{*}{$\begin{array}{l}\text { Normal } \\
\text { Parameters }\end{array}$} & $\begin{array}{l}\text { Std. } \\
\text { Deviatio } \\
\mathrm{n}\end{array}$ & ,95616398 \\
\hline & Absolute & ,092 \\
\hline \multirow[t]{2}{*}{$\begin{array}{l}\text { Most Extreme } \\
\text { Differences }\end{array}$} & Positive & ,079 \\
\hline & Negative &,- 092 \\
\hline \multicolumn{2}{|c|}{ Kolmogorov-Smirnov Z } & 692 \\
\hline \multicolumn{2}{|c|}{ Asymp. Sig. (2-tailed) } & ,724 \\
\hline
\end{tabular}


a. Test distribution is Normal.

b. Calculated from data.

Sumber : Hasil Olah Data, 2019

Berdasarkan Tabel 4.5, dapat dilihat bahwa nilai Asymp. Sig. (2-tailed) sebesar 0,724 > dari 0,05 , maka data tersebut terdistribusi dengan normal dan model regresi telah memenuhi asumsi normalitas.

\section{Pengujian Hipotesis}

\section{a. Pengujian Signifikan Parsial (Uji t)}

Uji parsial atas Pengaruh Pelatihan (X1) dan Promosi (X2) Terhadap Prestasi Kerja (Y) di Dinas Pertanian dan Peternakan Kabupaten Pinrang, dimaksudkan untuk mengetahui apakah Kedua variabel bebas tersebut secara persial berpengaruh terhadap Prestasi Kerja. Untuk mempermudah perhitungan regresi dari data yang cukup banyak, maka dalam penelitian ini diselesaikan dengan bantuan perangkat lunak (software) komputer yaitu program SPSS 21.0. Hasil uji parsial dapat dilihat pada Tabel 4.6.

\section{Tabel 4.6}

Hasil Uji Regresi

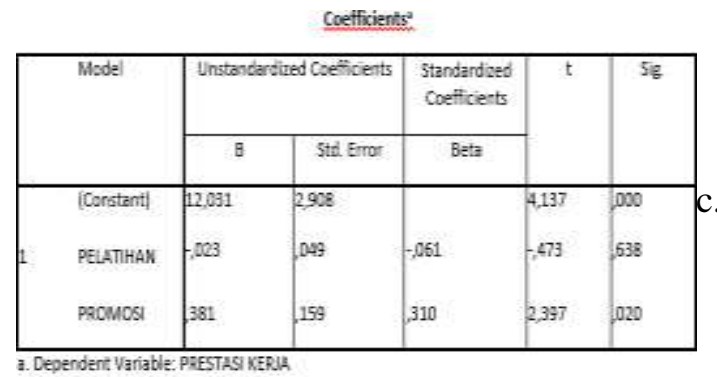

Sumber data diolah 2019

Pada penelitian ini digunakan model persamaan regresi linear berganda adalah sebagai berikut :

$$
Y=\alpha+\beta_{1} X_{1}+\beta_{2} X_{2}
$$

Dengan memperhatikan model regresi pada Tabel 4.6, maka didapat persamaan tentang Pengaruh Pelatihan (X1) dan Promosi (X2)Terhadap Prestasi Kerja (Y) di Dinas Pertanian dan Peternakan Kabupaten Majene sebagai berikut :

$\mathrm{Y}=12,031-0,061 \mathrm{X}_{1}+0,310 \mathrm{X}_{2}$

Model persamaan regresi sebelumnya dapat diartikan bahwa :
Jika Pelatihan nilainya adalah 0 , maka Prestasi Kerjaakan sama dengan konstantanya yaitu sebesar 12,031. Namun jika Pelatihan mengalami pertambahan sebesar 1 skor, maka akan menurunkan Prestasi Kerja sebesar 0,061 skor dengan asumsi variabel lain dalam kondisi konstan. Hasil uji signifikansi pada Tabel 4.6 menunjukkan nilai $t_{\text {hitung }}-0,473$ lebih kecil dari nilai $t_{\text {tabel }} 1,672$ dengan tingkat signifikansi t sebesar 0,638 yang nilainya lebih besar dari 0,05, maka dengan demikian hipotesis $\left(\mathrm{H}_{1}\right)$ ditolak, yang artinya Pelatihan berpengaruh tidak signifikan terhadap Prestasi Kerja di Dinas Pertanian dan Peternakan Kabupaten Majene.

Jika Promosi nilainya adalah 0, maka Prestasi Kerjaakan sama dengan konstantanya yaitu sebesar 12,031. Namun jika Promosi mengalami pertambahan sebesar 1 skor, maka akan meningkatkan Prestasi Kerjasebesar 0,310 skor dengan asumsi variabel lain dalam kondisi konstan. Hasil uji signifikansi pada Tabel 4.6 menunjukkan nilai $t_{\text {hitung }}$ 2,397 lebih besar dari nilai $t_{\text {tabel }} 1,672$ dengan tingkat signifikansi t sebesar 0,020 yang nilainya lebih kecil dari 0,05, maka dengan demikian hipotesis $\left(\mathrm{H}_{2}\right)$ diterima, yang artinya Promosi berpengaruh signifikan terhadap Prestasi Kerja di Dinas Pertanian dan Peternakan Kabupaten Majene.

Dari uji signifikansi pada Tabel 4.6 menunjukkan Variabel Pelatihan memiliki Standardized Coefficients Beta sebesar -0,061 sedangkan variabel Promosi memiliki Standardized Coefficients Beta sebesar 0,310. Variabel Promosi mempunyai pengaruh yang dominan terhadap Prestasi Kerja, maka dengan demikian hipotesis $\left(\mathrm{H}_{3}\right)$ ditolak, yang artinya Pelatihan bukan variabel yang dominan berpengaruh terhadap Prestasi Kerja di Dinas Pertanian dan Peternakan Kabupaten Pinrang

\section{b. Pengujian Signifikan Bersama (Uji F)}

Uji bersama atas Pengaruh Pelatihan (X1) dan Promosi (X2) Terhadap Prestasi Kerja di Dinas Pertanian dan Peternakan Kabupaten Pinrang, dimaksudkan untuk mengetahui apakah Kedua variabel bebas tersebut secara bersama atau serentak/simultan berpengaruh 
Sitti Mujahida Baharuddin, Warka Syachbrani,Analisis Pengaruh Pelatihan dan Promosi Terhadap Prestasi Kerja Pada Dinas Pertanian Dan Peternakan Kabupaten Pinrang $\mid 40$

terhadap Prestasi Kerja. Untuk mempermudah perhitungan regresi dari data yang cukup banyak, maka dalam penelitian ini diselesaikan dengan bantuan perangkat lunak (software) komputer yaitu program SPSS 21.0. Hasil uji simultan dapat dilihat pada Tabel 4.7.

\section{Tabel 4.7}

\section{Hasil Regresi Uji F}

Sumber data diolah 2019

Berdasarkan Tabel 4.7 hasil uji signifikan menunjukkan bahwa nilai $F_{\text {hitung }}$ 3,000 lebih besar dari nilai $\mathrm{F}_{\text {table }} 3,158$ dengan tingkat signifikansi $F$ sebesar 0,05 yang nilainya sama dengan 0,05 , maka dengan demikian Pelatihan (X1) dan Promosi (X2) berpengaruh signifikan terhadap Prestasi Kerja di Dinas Pertanian dan Peternakan Kabupaten Pinrang.

\section{c. Analisis Koefisien Determinasi}

Analisis koefisien determinasi $\left(\mathrm{R}^{2}\right)$ digunakan untuk mengetahui seberapa besar presentase sumbangan pengaruh variabel independen secara serentak terhadap variabel dependen. Nilai $\mathrm{R}^{2}$ ( $R$ Square) dapat dilihat pada Tabel 4.8.

\section{Tabel $\quad 4.8$}

Model Summary

\begin{tabular}{|l|r|r|r|c|}
\hline Model & R & R Square & $\begin{array}{c}\text { Adjusted R } \\
\text { Square }\end{array}$ & $\begin{array}{c}\text { Std. Error of the } \\
\text { Estimate }\end{array}$ \\
\hline 1 &, $316^{\mathrm{a}}$ &, 100 &, 067 & 2,921 \\
\hline
\end{tabular}

a. Predictors: (Constant), PROMOSI, PELATIHAN

Sumber : Hasil Olah Data, 2019

Berdasarkan Tabel 4.8 menunjukkan bahwa nilai $R$ Square sebesar 0,100 artinya $10,0 \%$ Kedua variabel independen (Pelatihan (X1) dan Promosi (X2) secara bersama-sama dapat menjelaskan model dari penelitian ini dan sisanya sebesar $90,0 \%$ dijelaskan oleh variabel atau faktor-faktor lain yang tidak diteliti atau tidak dimasukkan dalam model regresi.

\section{A. Pembahasan}

1. Pengaruh Pelatihan Terhadap Prestasi Kerja di Dinas Pertanian dan Peternakan Kabupaten Pinrang
Berdasarkan hasil pengujian pada hipotesis pertama (H1), menunjukkan bahwa Pelatihan berpengaruh tidak signifikan terhadap Prestasi Kerja di Dinas Pertanian dan Peternakan Kabupaten Pinrang, artinya hipotesis H1 diterima. Hasil ini tidak sejalan dengan penelitian yang dilakukan oleh Khairul Akhir Lubis (2008), Aldila Nursanti (2014) yang menyatakan bahwa Pelatihan berpengaruh signifikan terhadap

ANOVA $^{\mathrm{a}}$

\begin{tabular}{|rl|r|r|r|r|r|}
\hline Model & & $\begin{array}{c}\text { Sum of } \\
\text { Squares }\end{array}$ & df & $\begin{array}{c}\text { Mean } \\
\text { Square }\end{array}$ & F & Sig. \\
\hline \multirow{2}{*}{1} & $\begin{array}{l}\text { Regressi } \\
\text { on }\end{array}$ & 51,198 & 2 & 25,599 & 3,000 &, $058^{\text {b }}$ \\
& Residual & 460,837 & 54 & 8,534 & & \\
& Total & 512,035 & 56 & & & \\
\hline
\end{tabular}

a. Dependent Variable: PRESTASI KERJA

b. Predictors: (Constant), PROMOSI, PELATIHAN Kinerja Karyawan. Secara teori dan hasil empirik sebagian besat penelitian mengemukakan bahwa Program pelatihan pada intinya ditujukan untuk memperbaiki kinerja

apabila karyawan-karyawan yang bekerja secara tidak memuaskan karena kekurangan keterampilan merupakan calon utama pelatihan. Kendatipun pelatihan tidak dapat memecahkan semua masalah kinerja yang tidak efektif, program pelatihan yang sehat sering berfaedah dalam meminimalkan masalah ini. Adanya program pelatihan maka diharapkan karyawan lebih giat dalam menjalankan pekerjaannya sehingga apabila mereka giat dalam menjalankan pekerjaannya maka secara langsung prestasi kerja juga akan meningkat karena prestasi kerja berdasarkan adanya kecakapan, pengalaman, dan kesungguhan dalam melaksanakan yang diberikan oleh perusahaan. Hal ini terjadi disebabkan karena sebagaian besar responden menyatakan sangat tidak setuju, tidak setuju dan ragu-ragu terhadap; isi pelatihan kerja relevan dan sesuai dengan bidang kerja, Pelatih atau instruktur yang mengajari saya selama pelatihan kerja memiliki kualitas yang baik, Setelah mengikuti pelatihan kerja, lebih bisa mengerti dan menangani permasalahan dengan baik, bisa bekerja secara mandiri setelah mengikuti pelatihan kerja, pelatihan kerja mampu meningkatkan akurasi, ketelitian dan kehandalan dalam 
bekerja, pelatihan kerja meningkatkan kualitas dan produk dan servis.

2. Pengaruh Promosi Terhadap Prestasi Kerja di Dinas Pertanian dan Peternakan Kabupaten Pinrang

Berdasarkan hasil pengujian pada hipotesis kedua (H2), menunjukkan bahwa Promosi berpengaruh signifikan terhadap Prestasi Kerja di Dinas Pertanian dan Peternakan Kabupaten Pinrang, artinya hipotesis H2 diterima. Hal ini sejalan dengan hasil penelitian yang dilakukan oleh Puji Fatmawati (2013) yang menyatakan bahwa Promosi mempunyai pengaruh yang signifikan terhadap prestasi kerja. Pada dasarnya pegawai yang mempunyai keinginan mengalami kenaikan jabatan yang tinggi akan cenderung mempunyai kinerja yang tinggi. Kinerja dinyatakan sebagai suatu perwujudan kerja aparatur yang selanjutnya akan dijadikan dasar penilaian atas tercapai atau tidaknya target dan tujuan dalam organisasi.

3. Variabel Pelatihan memiliki Standardized Coefficients Beta sebesar -0,061 sedangkan variabel Promosi memiliki Standardized Coefficients Beta sebesar 0,310. Variabel Promosi mempunyai pengaruh yang dominan terhadap Prestasi Kerja, maka dengan demikian hipotesis $\left(\mathrm{H}_{3}\right)$ ditolak, yang artinya Pelatihan bukan variabel yang dominan berpengaruh terhadap Prestasi Kerja di Dinas Pertanian dan Peternakan Kabupaten Pinrang.

\section{SIMPULAN DAN SARAN}

Dari rumusan masalah, hipotesis, hasil penelitian dan pembahasan, dapat dikemukakan beberapa kesimpulan sebagai berikut:

1. Hasil uji signifikansi pengaruh Pelatihan terhadap Prestasi Kerja menunjukkan nilai $\mathrm{t}_{\text {hitung }}-0,473$ lebih besar dari nilai $\mathrm{t}_{\text {tabel }} 1,672$ dengan tingkat signifikansi t sebesar 0,638 yang nilainya lebih kecil dari 0,05 , maka dengan demikian hipotesis $\left(\mathrm{H}_{1}\right)$ diterima, yang artinya Pelatihan berpengaruh signifikan terhadap Prestasi Kerja di Dinas Pertanian dan Peternakan Kabupaten Pinrang.

2. Hasil uji signifikansi pengaruh Promosi terhadap Prestasi Kerja menunjukkan nilai $\mathrm{t}_{\text {hitung }} 2,397$ lebih besar dari nilai $\mathrm{t}_{\text {tabel }} 1,672$ dengan tingkat signifikansi t sebesar 0,020 yang nilainya lebih kecil dari 0,05 , maka dengan demikian hipotesis $\left(\mathrm{H}_{2}\right)$ diterima, yang artinya Promosi berpengaruh signifikan terhadap Prestasi Kerja di Dinas Pertanian dan Peternakan Kabupaten Pinrang.

3. Variabel Pelatihan memiliki Standardized Coefficients Beta sebesar -0,061 sedangkan variabel Promosi memiliki Standardized Coefficients Beta sebesar 0,310. Variabel Promosi mempunyai pengaruh yang dominan terhadap Prestasi Kerja, maka dengan demikian hipotesis $\left(\mathrm{H}_{3}\right)$ ditolak, yang artinya Pelatihan bukan variabel yang dominan berpengaruh terhadap Prestasi Kerja di Dinas Pertanian dan Peternakan Kabupaten Pinrang.

\section{DAFTAR RUJUKAN}

Aldila Nursanti, 2014. Pengaruh Pelatihan Kerja Dan Pemberian Insentif Terhadap Kinerja Karyawan CV Kedai Digital Yogyakarta. Program Studi Manajemen - Jurusan Manajemen. Fakultas Ekonomi. Universitas Negeri Yogyakarta

Arikunto, Suhasimi, 2006, Prosedur Penelitian Suatu Penddekatan Praktik, Rineke Cipta, Jakarta

Daryanto., (2013), Sari Kuliah Manajemen Produksi, Satu Nusa, Bandung.

Dessler, 2007. Manajemen SDM. Jilid II. PT. Erlangga : Jakarta

Endang, Sri dkk., (2010), Modul Memahami Prinsip-Prinsip Penyelenggaraan Administrasi Perkantoran, Erlangga. Jakarta

Fanada, Mery. 2012. Mind Set (Pola PikirP Pimpinan Melihat Prestasi Kerja Pegawai dalam Promosi Jabatan. http://www.banyuasinkab.go.id/tampun g/ dokumen/dokumen-15-46.pdf

Fathoni, Adburrahman, 2006. Organisasi dan Manajemen Sumber Daya Manusia, Rineka Cipta, Jakarta 
Sitti Mujahida Baharuddin, Warka Syachbrani,Analisis Pengaruh Pelatihan dan Promosi

Terhadap Prestasi Kerja Pada Dinas Pertanian Dan Peternakan Kabupaten Pinrang $\mid 42$

Puji Fatmawati, 2013. Pengaruh Promosi Jabatan Terhadap Kinerja Pegawai Di Dinas Pendapatan Pengelolaan Keuangan Dan Asset (DPPKA) kabupaten kulon progo. Program studi akuntansi DIII Fakultas Ekonomi Universitas Negeri Yogyakarta

Ghozali, Imam, 2006. Aplikasi Analisis Multivariate Dengan Program SPSS, Semarang : Badan Penerbit Diponegoro

Handoko, T. Hani. 2001. Manajemen Personalia dan Sumber Daya Manusia. Edisi II. Yogyakarta: BPFE

Handoko, T. Hani, 2008. Manajemen Personalia dan Sumber Daya Manusia, Edisi kedua, BPFE, Yogyakarta

Hanggraeni, Dewi., (2012), Manajemen Sumber Daya Manusia, Lembaga Penerbit Fakultas Ekonomi Universitas Indonesia. Jakarta

Hasibuan, Malayu S.P. 2011. Manajemen Sumber Daya Manusia. Jakarta: PT Bumi Aksara

Judas, Agnetha. 2013. Mutasi Dan Promosi Jabatan Pengaruhnya Terhadap Prestasi Kerja Pegawai Pada Kanwil Ditjen Kekayaan Negara Suluttenggo Dan Maluku Utara Di Manado. Jurnal EMBA Vol.1 No.4 Desember 2013, Hal. 1219-1228. ISSN 2303-1174

Kasmir., (2008), Manajemen Perbankan, PT Rajagrafindo Persada. Jakarta

Khairul Akhir Lubis (2008), Penagruh Pelatihan dan Motivasi Kerja Terhadap Kinerja Karyawan PT. Perkebunan Nusantara IV (Persero) Medan. Tesis. Sekolah Pascasarjana. Universitas Sumatera Utara. Medan

Manullang, Marihot. 2008 Manajemen Personalia. Gadjah Mada University Press. Yogyakarta

Mangkunegara Anwar Prabu, 2009. Manajemen Sumber Daya Manusia Perusahaan, Cetakan Keenam, PT. Remaja Rosdakarya, Bandung
M Kadarisman (2012). Manajemen Kompensasi. Jakarta : Rajagrafindo Persada

Malhotra, Naresh, 2007. Marketing Research : an applied orientation, pearson education, inc., fifth edition. New Jearsey : USA

Martoyo, Susilo. 2007. Manajemen Sumberdaya Manusia. Edisi 5. BPFE. Yogyakarta

Mathis, Robert L. dan John, H. Jackson. 2009. Human Resource Management. Edisi 10. Jakarta : Salemba Empat

Moekijat., (2010), Manajemen Sumber Daya Manusia, Mandar Maju. Bandung

Meokijat, 1996. Manajemen Kekaryawanan, Mandar Maju, Bandung.

Nasution, Mulia, 2000. Manajemen Personalia, Djambatan, Jakarta.

Nitisemito, Alex. 2002. Manajemen Personalia. Jakarta: Ghalia Indonesia

Ratnasari, Sri Langgeng. Pengaruh FaktorFaktor Pelatihan Terhadap Prestasi Kerja Karyawan Departemen Produksi PT. X Batam. Buletin Studi Ekonomi. Volume 18 No 1. Februari 2013. ISSN $1410-4628$

Sekaran, Uma. 2006. Metodologi Penelitian untuk Bisnis, Buku 2 Edisi 4. Jakarta: Salemba Empat

Setiawan, I Wayan Oky dan Ni Ketut Sariathi. 2013. Pengaruh Kompensasi Finansial, Promosi Jabatan dan Lingkungan Fisik Terhadap Kepuasan Kerja pada Parigata Resort and Spa Sanur, Bali. EJurnal Manajemen, 2(7): pp:786- 801

Siagian, Sondang. P., (2011), Manajemen Stratejik, Bumi Aksara. Jakarta

Siagian, Sodang P. (2014). Manajemen sumber daya manusia. Jakarta: Bumi Aksara. 
Simamora, H. 2004. Manajemen Sumber Daya Manusia. Edisi Ketiga. Yogyakarta: Sekolah Tinggi Ilmu Ekonomi YKPN

Soeprihanto, John. 2007. Penilaian Kinerja dan Pengembangan Karyawan, PT. PBFE Yogyakarta

Suprianto, Achmad Sani \& Machfudz Masyhuri. 2010. Metodologi Riset Manajemen Sumber Daya Manusia. Malang: UIN-Maliki Press (Anggota IKAPI)

Swasto, Bambang. 2003. Pengembangan Sumber Daya Manusia Pengaruhnya Terhadap Kinerja dan Imbalan. Malang: FIA UB

Tanjung dan Arep, 2008. Manajemen Sumber Daya Manusia. Edisi Kedua. Yogyakarta : BPEC
Umar, Huzein, 2001. Riset Sumber Daya Manusia. Cetakan Keempat. Penerbit PT. Gramedia Pustaka Utama. Jakarta.

Warnanti, Asri. 2014. Pengaruh Pelatihan, Motivasi Dan Lingkungan Kerja Terhadap Prestasi Kerja Karyawan Pada PT. Bank Central Asia Tbk Cabang KCU Thamrin Jakarta Pusat. Jurnal Serambi Hukum Vol. 08 No. 02 Agustus 2014 - Januari 2015. ISSN: 1693-0819

Peraturan Menteri Keuangan Nomor 39/PMK.01/2009 tentang pola mutasi jabatan karier di lingkungan Departemen Keuangan Menteri Keuangan

Peraturan Pemerintah Nomor 9 Tahun 2003 yaitu tentang wewenang Pengangkatan, Pemindahan dan Pemberhentian Pegawai Negeri Sipil 